\title{
ARTISTAS Y CAZADORES DE CIERVOS. EL PAPEL DEL CIERVO EN EL ARTE Y LA CAZA DEL PALEOLÍTICO SUPERIOR CANTÁBRICO
}

\author{
Red deer artists and hunters. The rol of deer in the art and hunt \\ of the Upper Palaeolithic in the cantabric area
}

\author{
Mario Menéndez Fernández y José Manuel Quesada López* \\ Recibido el 7 de febrero de 2008. Aceptado el 10 de marzo de 2008.
}

\begin{abstract}
Resumen. El ciervo fue el animal prioritario en las prácticas de caza para las comunidades paleolíticas cantábricas y al mismo tiempo una de las especies más representadas en el Arte paleolítico. Este artículo propone algunas relaciones sugerentes entre las características ecológicas, su papel dominante en las estrategias de caza y los rasgos iconográficos de la especie durante el Paleolítico superior cantábrico. Palabras clave: Ciervo. Paleolítico superior. Cornisa cantábrica. Caza paleolitica. Arte paleolítico.
\end{abstract}

\begin{abstract}
Red deer was the most important animal species hunted for food by Upper Palaeolithic inhabitants of Cantabrian region and almost it was one of the principal animals in Palaeolithic Art. This paper point out some suggestive relations about special ecological character, dominant role in hunt strategies and ichnographical record of this specie in Cantabrian Upper Paleolitihic.

Key Words: Red deer. Upper Palaeolithic. Cantabrian region. Palaeolithic hunting. Palaeolithic Art.
\end{abstract}

A lo largo de la historia de la humanidad y desde una perspectiva ecológica que integra a los grupos humanos como una especie más en la naturaleza, todos los grupos cazadores recolectores han mantenido una especial relación con alguna especie animal. En el Paleolítico superior cantábrico esa especie es, sin duda, el ciervo. Tanto desde el punto de vista estrictamente económico como desde un acercamiento cultural. En el primer caso, muchos yacimientos definen su actividad económica como especializada en la caza de estos ungulados, sobre todo durante el Solutrense y Magdaleniense. Otros, condicionados por el biotopo y el ecosistema circundante, eligen otras especies como eje central de capturas, tales como cabras o rebecos. Sin embargo, en el Cantábrico, durante todo el Paleolítico superior, el ciervo siempre aparece como una parte importante de la dieta cárnica. Así, si en otros ámbitos europeos y americanos, los cazadores recolectores del Tardiglacial pueden ser definidos como cazadores de renos, de mamuts o de bisontes; los cazadores cantábricos de esa misma época podrían ser definidos, por defecto, como cazadores de ciervos.

Aunque se haya argumentado en numerosos trabajos, como veremos, que no hay una relación unívoca y directa entre los animales cazados y los representados en el arte rupestre y mobiliar paleolítico (Altuna, 1994), existe, sin duda, una motivación económica y cultural en la presencia constante de ciervos en el imaginario artístico paleolítico. Incluso en algunos momentos concretos donde en otros ámbitos europeos otras especies animales cobran un protagonismo especial, en el cantábrico se representan profusamente ciervos y ciervas según modelos y convenciones rígidamente establecidos. Ello es indicativo de una presencia de esta especie animal que va más allá de lo estrictamente económico y se asienta como un tema central en el universo simbólico de los cazadores recolectores cantábricos. 
Con este trabajo queremos solamente hacer unas reflexiones generales sobre la presencia del ciervo en el cantábrico tardiglacial, su naturaleza y etología, para una mejor comprensión de su importancia en la dieta y en el mundo simbólico de los cazadores recolectores. Dedicar este trabajo al profesor Ripoll Perelló, con quien tuvimos el honor de compartir docencia durante un tiempo en el Departamento de Prehistoria de la UNED, es una modesta contribución a quien nos dejó reflexiones tan lúcidas sobre el arte paleolítico y la comprensión del bestiario representado en las cuevas cantábricas.

\section{EL CIERVO EN LA NATURALEZA: DEL HÁBITAT A LA ETOLOGÍA}

Entre los animales que han sido objetivo tradicional de caza, el ciervo constituye uno de los trofeos más emblemáticos. El porte altivo y majestuoso de los machos adultos, con sus grandes cornamentas, así como la esbeltez, gracilidad y elegancia de las ciervas en sus movimientos, los han hecho objeto de admiración y los ha convertido en presa codiciada. Hay que tener en cuenta que proporcionan además un volumen considerable de carne de excelente calidad y que proveen muchos otros productos secundarios de gran utilidad para los cazadores paleolíticos, tales como grandes astas, huesos sólidos, largos tendones, pieles de calidad apreciable, etc. Además, su caza no implica el riesgo de otros animales más peligrosos. Por ello, además de otras razones de naturaleza cultural que podemos intuir pero que se nos escapan, el ciervo está presente en todas las sociedades que practican la caza como medio de subsistencia o como cuestión de prestigio. Esto es singularmente importante en el Paleolítico cantábrico, como veremos.

Taxonómicamente el ciervo común o venado de la península Ibérica se clasifica como Orden: Artiodáctilos; Familia: Cérvidos; Género: Cervus; Especie Cervus elaphus; subespecie: Cervus elaphus bolivari. Suelen citarse hasta 27 subespecies que ocupan Europa, la franja templada central del continente asiático, América del Norte y norte de África. Sin embargo, los estudios genéticos más recientes realizados sobre el mtDNA muestran una mayor complejidad interna a nivel de especie de la que parece indicar la simple morfología. Además estos estudios señalan un origen para la misma en Asia central, separándose las formas orientales y las occidentales hace siete millones de años (Ludt et al., 2004). En la península lbérica, la forma más común es la subespecie bolivari, conociéndose otra especie circunscrita fundamentalmente a las marismas del Guadalquivir, taxonómicamente definida como Cervus elaphus hispanicus.

El ciervo común, tal como lo conocemos en el Cantábrico, se configura hace casi medio millón de años, durante la glaciación Mindel en términos geológicos clásicos. Las primeras variedades del ciervo rojo aparecieron más concretamente a finales del Pleistoceno inferior, aunque la variedad actual se configuró a partir de la evolución local de los cérvidos que habitaban el continente europeo en el Pleistoceno medio, en torno al 550.000 BP. (que corresponde a la etapa OIS14). Por entonces también aparecieron otros tipos de cérvidos como los gamos y los corzos, que hallaron buen acomodo en las tierras europeas.

Este animal ha sido considerado habitualmente como una especie boscosa pero posee una notable capacidad de adaptación ambiental (ver Corbet, 1966, entre los muchos manuales al respecto). Actualmente el ciervo posee una distribución muy amplia pues se halla en las regiones paleártica, índica y neártica. En realidad se trata de una especie holártica, pero que se desenvuelve con soltura excelente en multitud de biomas: bosques caducifolios, taigas, zonas subtropicales, estepas... Los estudios sobre el ciervo europeo muestran su preferencia por los bosques caducifolios con rasos, al tiempo que su adaptación a los bosques de coníferas -sobre todo si presentan claros- y zonas cubiertas por el típico matorral mediterráneo. Hallamos también poblaciones de ciervos en las altiplanicies casi totalmente desprovistas de bosques, similares a las llanuras norteamericanas y los páramos brezales de Escocia (Darling, 1963). E incluso ocupan las áreas netamente montañosas, en cuyo caso no suele superar el límite forestal superior, de manera que su intromisión en las montañas más desnudas se debe a la presión humana, a la extensión de los cultivos y deforestación. En todo caso su impronta boscosa le induce a buscar refugio en bosques de invierno, sobre todo cuando acontecen tempestades o nevadas duras y espesas que ocultan los pastos y hierbas.

Buena parte de la capacidad de adaptación del ciervo deriva de sus costumbres alimenticias, pues es el cérvido que presenta los hábitos dietéticos más flexibles (Straus, 1981 presenta un excelente resumen de los estudios sobre la dieta de la especie). Tiene preferencia por el consumo de hierbas, flores, hojas, yemas, brotes jóvenes y diversos frutos como las bellotas, hayucos, castaños, moras... Pero no desdeña productos menos alimenticios pues ramonea hojas, cortezas de árboles, pequeñas ramas, brezos, hongos, agujas de coníferas e incluso líquenes si fuera necesario... Este último tipo de alimentación resulta habitual en tiempos de necesidades alimenticias como los períodos invernales de nevadas o en los momentos previos a la brotación de las hierbas y demás plantas de la pradera. Tal como veremos, el patrón alimenticio puede haber sido importante en la densidad de las poblaciones cantábricas.

Para comprender la etología de la especie es necesario considerar su marcado dimorfismo sexual (Corbet, 1966). Mientras los machos llegan a alcanzar los $250 \mathrm{~cm}$ de longitud y más de $200 \mathrm{~kg}$ de peso, las hembras superan ligeramente la mitad de esos valores. Pero la diferencia más marcada es la ausencia de cuernos en las hembras. También las huellas de la pisada y los excrementos muestran la diferencia de sexo, lo 
que sin duda es relevante para los cazadores paleolíticos pues el conocimiento de los animales y su comportamiento es una competencia ineludible. Además de esta diferencia en la corpulencia y las astas, también en el color de la piel existen algunas diferencias entre machos y hembras, siendo aquellos de un color pardo rojizo más oscuro, con zonas blanquecinas en vientre y glúteos. Las crias de pocos meses presentan rayas y manchas en la piel, lo que facilita su camuflaje entre hierbas y arbustos. Finalmente, los ciervos tienen unos Ilamativos lacrimales en los ojos, con glándulas odoriferas, que utilizan para marcar el territorio, como el orín en la época de celo. Todos estos elementos identificativos, más o menos exclusivos, tales como porte 0 actitud, cuernas, coloración de la piel, lacrimales, etc. aparecen recogidos en las representaciones paleolíticas, a veces como simple trazo escueto definitorio y otras como elaborada composición.

La cornamenta de los machos es uno de los rasgos anatómicamente más característicos y mejor conocidos, que fue evolucionando desde su origen en el Plioceno, ganando en complejidad y tamaño en los machos adultos. Esta parte tan emblemática de su morfología ha sido muy estudiada y descrita con numerosos términos, a veces con marcado carácter local, en todas las lenguas, mereciendo destacarse las correlaciones establecidas entre el número de puntas y la edad de los machos. Si bien con el paso del tiempo las cornamentas se van haciendo más grandes y complejas, no existe una relación directa entre años y número de puntas (Azorit et alii, 2002), sino más bien que esta correlación puede establecerse a partir del tamaño y longitud de las astas. No obstante, la edad del ciervo, como otros ungulados, se mide a partir de los cortes histológicos de los molares. Sin embargo, recientemente si se ha establecido una relación directa entre el tamaño y complejidad de las cuernas y la fertilidad de los machos, comparándolas con su número y vitalidad de espermatozoides (Gomedio et al., 2005); por lo cual éstas no serían sólo un arma o defensa para la lucha en la berrea, sino también una señal para las hembras que han de elegir el macho con el que aparearse durante la época de celo. Hay que tener en cuenta que los machos pierden sus magníficas cornamentas anualmente y las renuevan con un enorme esfuerzo metabólico. Este dispendio energético, o desmogue, se produce a finales de marzo, comenzando inmediatamente a brotar unas nuevas. Aparecen cubiertas de una piel aterciopelada y muy vascularizada, denominada borra. En julio la cornamenta ya alcanza su punto óptimo, desprendiéndose la borra. Para ello el ciervo se frota contra los árboles, proceso que se denomina escoda, dejando un rastro de cortezas peladas bien conocido por los cazadores.

El ciervo es una especie predominantemente gregaria pero tal gregarismo está condicionado por el sexo. De un lado se reúnen las hembras con las crías y de otro los machos de más de tres años. Los dos grupos viven separados la mayor parte del año y se comportan de muy distinta manera. Las manadas de hembras se componen de la madre y las dos 0 tres crías de los últimos años. Dentro de las grandes manadas constituidas por la reunión de varias de esas familias, las hembras más viejas dominan con estricta jerarquía los desplazamientos, la elección de pastos y lugares de descanso, mostrando una conducta muy territorial y carácter estacional, hasta el punto de no dudar en defender su área de otros rebaños. Por contra, los grupos de machos son más reducidos y sus lazos de unión menos estables; en realidad son meros agregados donde cada animal se preocupa solo de su propia seguridad y no muestran una territorialidad tan marcada como las hembras. Los machos más viejos viven solitarios y aislados. Pero tanto los rebaños de hembras como los de machos son errantes, sin repetir con frecuencia los encames, con hábitos crepusculares y nocturnos, pasando el día agazapados y rumiando en un lugar que considera seguro. La época del celo, a finales del verano, revoluciona los comportamientos volviendo a los machos violentos y egoístas; tan obsesionados por la reproducción que se olvidan incluso de comer. Pelean entre ellos por el harem de hembras, berrean y marcan obsesivamente el territorio.

El dimorfismo sexual y social tiene además consecuencias en el comportamiento territorial de las manadas. Los grupos de hembras y de machos ocupan territorios distintos en verano y en invierno. Durante la época estival habitan las zonas altas, que gozan de un clima más fresco, frecuentando las vertientes norte de las cordilleras y los sitios sombríos y húmedos. En invierno descienden a zonas bajas y abrigadas, sobre todo de las vertientes meridionales, buscando los rasos, descubiertos y soleados. En la época de celo, que acontece a finales de septiembre y en octubre, los machos abandonan sus territorios y van en busca de las hembras, proclamando su propiedad con bramidos en el período llamado berrea 0 brama. Durante esta época las hembras mantienen su independencia y los machos no toman el liderato del rebaño de hembras, que mantiene su estructura matriarcal hasta el punto de que en caso de peligro presentan actitudes distintas: los machos huyen por su lado y no se preocupan en absoluto de sus compañeras ocasionales, que huyen por su cuenta y como siempre ordenadamente. Tras la época de celo, los machos abandonan los territorios de las hembras, alejándose a veces mucho, para formar grupos sueltos hasta la estación reproductora del año siguiente.

La gestación dura unas cuarenta semanas, pariendo las hembras una o, rara vez, dos crías a finales de mayo o comienzos de junio. Este proceso se realiza cada dos años, descansando uno tras cada parto. La hembra parturienta se separa de su rebaño y retira al bosque, junto con las crías de los años anteriores, recostándose en un lugar escondido para parir. En esas parideras, que son lugares fijos, se produce un rápido parto, de apenas 10 minutos. Los tres primeros días son los más difíciles para la supervivencia del cervato pues está prácticamente indefenso y gran número de ellos pierde 
la vida por el ataque de sus enemigos depredadores (lobo, zorros, linces, gatos monteses, águilas...). Después de una semana huye y se esconde entre la hierba al aviso de peligro. Durante tres meses tomará leche exclusivamente, permaneciendo junto a su madre hasta la aparición de un nuevo celo. Entonces los machos jóvenes buscan un territorio propio y las hembras forman rebaño con su madre.

\section{EL CIERVO EN LAS PRÁCTICAS DE CAZA: DE LA CAZA SELECTIVA A LAS MATANZAS COLECTIVAS...}

La presencia de restos de ciervos en todos los yacimientos de la cornisa cantábrica y las altas proporciones que alcanzan en muchos de ellos, sancionan la caza de este animal como un pilar esencial en la subsistencia de los cazadores del Paleolítico superior cantábrico. Ese papel guarda relación con las condiciones ambientales que reinaron en el continente desde el Pleniglaciar y sobre todo durante el último máximo glaciar. La crudeza climática del 18.000 BP. a buen seguro que provocó la migración de las manadas de ciervos desde las planicies del suroeste de Francia hacia las costas cantábricas, probablemente de manera abundante pues los restos del ciervo en los yacimientos más meridionales de Las Landas francesas no son más que minoritarios (Altuna, 1995). En los abrigados valles cantábricos el ciervo pudo hallar unas condiciones no del todo óptimas pero en cualquier caso aptas (Altuna, 1995) por la amplia gama de posibilidades ambientales, refugios boscosos caducifolios, pinares, praderas de herbáceas, páramos de brezales...

Respecto a la importancia global del ciervo en relación a otras especies, tanto en el arte como en la dieta, debemos establecer importantes matices tanto de orden cronológico como geográfico. Machos y hembras no pueden separarse sistemáticamente en las cuantificaciones arqueozoológicas, de manera que forman un único capítulo del recuento faunístico. En términos muy generales los ciervos suponen globalmente en el Cantábrico más de la mitad de los restos animales documentados en los yacimientos. Recientemente, Demars (2007) ha cuantificado los restos de ungulados en Europa en dos grupos, con una división hacia el 17.000 BP.: el Pleniglaciar, con un 56.7\% de ciervo en el Cantábrico, y el Tardiglaciar, con un 64.8\%. La división indudablemente podría matizarse, pero muestra claramente que el ciervo supone a lo largo de todo el Paleolítico superior (no se incluye el Magdaleniense final) un papel primordial entre los nutrientes cárnicos. Son, con mucha diferencia, los valores más altos del continente europeo durante el Pleniglaciar. Sólo comparables con la España mediterránea (46.3\%) e Italia (56.3\%) en el Tardiglaciar, y muy alejados del resto de áreas de estudio europeo, incluyendo los Balcanes. En este sentido es interesante señalar el cambio diacrónico que se opera en Italia a lo largo del Paleolítico superior, pasando de cazadores de rebecos a cazadores de ciervos.
Recientemente hemos conocido datos muy interesantes para calibrar la trascendencia del ciervo en las prácticas de subsistencia de los primeros tiempos del Paleolítico superior. Las excavaciones realizadas recientemente en El Castillo han revelado que en el $38.000 \mathrm{BP}$. el ciervo ya era la presa más codiciada por los cazadores hasta posibilitar la acumulación de miles de huesos procedentes de unos 170 individuos. En el entorno de Monte Castillo la especie constituyó la presa principal probablemente por la combinación de varios factores: el entorno idóneo de masas boscosas de pinos y caducifolios (incluso tipos mediterráneos) a juzgar por los resultados polínicos; la ubicación en las rutas migratorias que comunicaban las tierras bajas y altas; y la proliferación de sitios perfectos para las prácticas de acoso y acorralamiento de los animales.

Las noticias que proporciona Cueva Morín para el 25.000 BP. confirman que el ciervo era también la presa más codiciada en las praderas herbáceas que cubrian las tierras del bajío costero en aquellos tiempos del Paleolítico superior inicial. Pero la intensidad de caza en la rica zona costera que circunda la depresión de la actual bahía de Santander parece que fue relativamente discreta. Los niveles gravetienses del yacimiento muestran que el ciervo sólo protagonizó una de cada tres capturas, muy a la par que los grandes animales de pradera (caballos, bisontes y bóvidos), que por su mayor volumen resultarian más importantes en la dieta (Freeman, 1971). Esta situación se repite en la angosta planicie del oriente asturiano a juzgar por el yacimiento de La Riera, donde las manadas de caballos fueron tanto o más codiciadas que los rebaños de ciervos en el período presolutrense.

La excelente capacidad de adaptación ambiental que tiene el ciervo pudo convertirle en una opción idónea para las comunidades humanas que afrontaron la profunda crisis climática en el máximo glaciar que concurrió en el $18.000 \mathrm{BP}$, correspondiente a la etapa isotópica OIS2 o Inter Laugerie/Lascaux de la terminología polínica. Por lo que muestran los niveles solutrenses de esa época no hubo retroceso destacable en la caza del ciervo, lo que podríamos achacar a la capacidad de resistencia de este animal y a que la intensidad de las capturas no puso en riesgo la capacidad de recuperación de sus manadas. El yacimiento de La Riera nos proporciona una imagen muy nítida de lo que pudo ser el escenario de caza del ciervo entonces por unas rasas litorales con una pobre cubierta vegetal de brezales que ofrecian un alimento de poca calidad nutritiva. Esta imagen nos evoca de manera inmediata los paisajes de landas que hoy cubren zonas con notables rebaños de ciervos como sucede actualmente en las montañas escocesas (Straus, 1981). Podemos pensar en manadas más o menos grandes, que sobreviven ramoneando entre páramos pero buscando refugios en las zonas protegidas, soleadas y húmedas de los bosquecillos.

En la mayoría de las cuevas cantábricas del período no hay pruebas de que los cazadores cantábricos incrementaran 
la presión de caza sobre las manadas de ciervos. De acuerdo con nuestros cálculos, por término medio estos animales no representaron más que una de cada tres capturas, lo que constituyó una tasa muy discreta, que recuerda tiempos pasados gravetienses. Pero hay ciertos interrogantes muy interesantes en las actitudes de caza de este período climático crítico. En momentos avanzados pero todavía crudos del mismo los cazadores solutrenses que habitaban en La Riera prueban claramente la intensificación de la caza del ciervo (Quesada, 1995, 1998), en lo que constituye la antesala de las prácticas especializadas de caza. Los datos demuestran claramente que los ciervos protagonizaron cuatro de cada cinco capturas, abasteciendo a los grupos humanos durante todo el año pues hay restos de caza en todos los momentos, incluyendo repuntes discretos en momentos críticos para la supervivencia del ciervo como los rigores severos del invierno y la delicada época próxima a la reproducción.

Resta por saber si la intensificación de la caza del ciervo registrada en La Riera representa una pauta generalizada para la Cornisa cantábrica al final del Solutrense superior o no es más que la actuación aislada de un grupo de cazadores en un área concreta. Este interrogante responde a una controversia

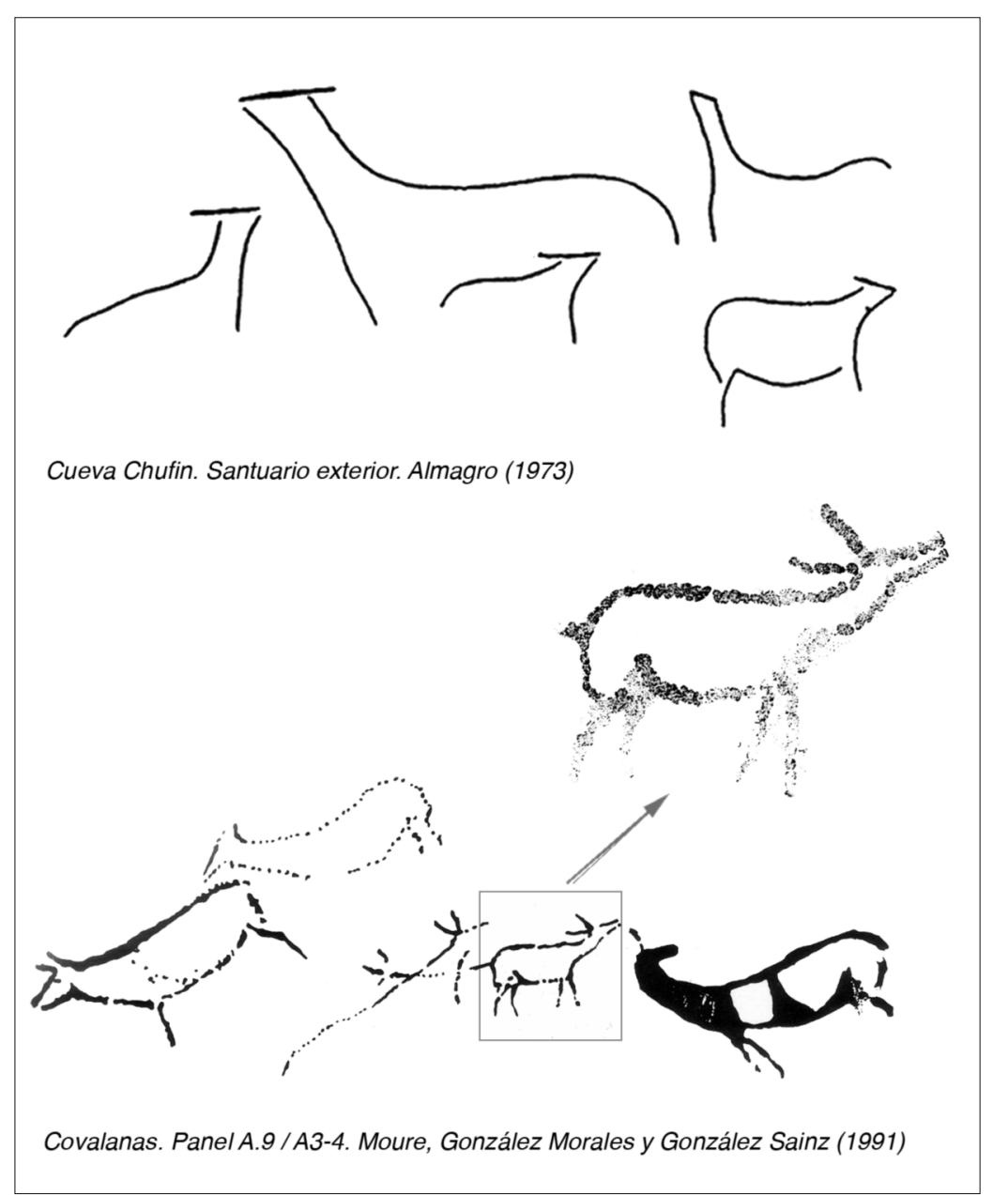

- Figura 1. Paneles de cérvidos del Estilo III. Grabado profundo de los "santuarios exteriores" (Chufín) y pintura roja de la "Escuela de Ramales" (Covalanas). habida en los años setenta/ochenta, que ha permanecido larvada hasta ahora sin respuesta categórica. Los primeros estudios paleoeconómicos para el Paleolítico cantábrico, firmados por el prehistoriador norteamericano L.G.Freeman (1973), proponían que la caza solutrense era producto de una escena diversificada pues carecía de interés intencionado selectivo por una especie concreta, posponiendo la implantación de la caza especializada al período magdaleniense. No mucho más tarde, el también prehistoriador norteamericano L. G. Straus (1983) propuso que las prácticas de caza solutrenses tenían una impronta inequivocamente especializada al existir pruebas de una concentración inusitada de capturas en torno, precisamente, a los ciervos. El argumento principal para sostener la hipótesis es la acumulación de cantidades ingentes de restos de ciervo en los niveles solutrenses de los yacimientos asturianos de La Riera y El Cierro. Pero no se trata del único argumento...

La hipótesis de caza especializada presenta otra dimensión no menos interesante. Según L. G. Straus la intensificación de las capturas de ciervos en tiempos solutrenses es resultado de la implantación de nuevas conductas de caza, por cuanto los cazadores ya no pretenden sólo abatir de manera selectiva ciertos individuos del rebaño, sino atrapar la mayor cantidad posible de cabezas mediante matanzas indiscriminadas (Straus 1983). Para justificar tal hipótesis Straus propuso la presencia de perfiles catastróficos de mortandad de ciervos en niveles de La Riera y Altamira: muestras combinadas de ciervos de todas las edades (animales seniles, adultos, juveniles, incluso cervatillos recién nacidos) que son una copia de la composición natural de las manadas.

Han transcurrido veinte años desde que apareció la controversia y no se ha avanzado gran cosa en su resolución, probablemente porque no tenemos la calidad y cantidad oportuna de datos. Pero en nuestra opinión hay dos importantes matices que considerar para encarar la cuestión. En primer lugar, que las pruebas de caza especializada de ciervos son indudables en los niveles solutrenses de La Riera datados en momentos avanzados del máximo glaciar, situados grosso modo en los 18.000-17.000 BP. (Quesada, 1995). En segundo lugar, que no hay datos solutrenses suficientes para asegurar la generalización de este comportamiento a la Cornisa cantábrica, por lo que resulta más prudente retrasar tal marco a los primeros tiempos magdalenienses (Quesada, 1998). De modo que en cierto sentido las dos hipótesis tienen su parte de razón. Más complicado resulta a nuestro juicio la 
propuesta que identifica intrínsecamente la caza especializada con tácticas de matanzas indiscriminadas por multitud de razones: no se han publicado aún los perfiles de mortandad, los disponibles no responden exclusivamente al modelo catastrófico, no se han considerado las disparidades entre manadas de hembras y machos, no es posible identificar los perfiles con un único evento de caza...

Lo que parece indiscutible es la implantación generalizada de la caza especializada de los ciervos en los primeros tiempos magdalenienses, en un momento que podemos situar hacia el 17.000 BP. Los datos paleontológicos conocidos por entonces en yacimientos distantes permiten reconocer sin ambages cómo el ciervo protagonizó cuatro de cada cinco capturas en lugares como La Paloma, La Riera, Ekain o Urtiaga. En ciertos entornos como los bajíos costeros de las comarcas cántabras situados junto a yacimientos como Altamira o El Juyo, que previsiblemente tenían mayor riqueza ambiental y gama potencial de recursos de caza, los ciervos constituyeron unas dos terceras partes de las capturas. Bien podemos decir que la especie se convirtió en la presa más codiciada por doquier en las tierras bajas e incluso ciertas montañas interiores, y en un pilar principal de la dieta humana a pesar de que las especies de pradera como caballos, bisontes y grandes bóvidos aún aportaban una importante cantidad de las necesidades alimenticias en ciertos lugares como Altamira. Este incremento de la caza

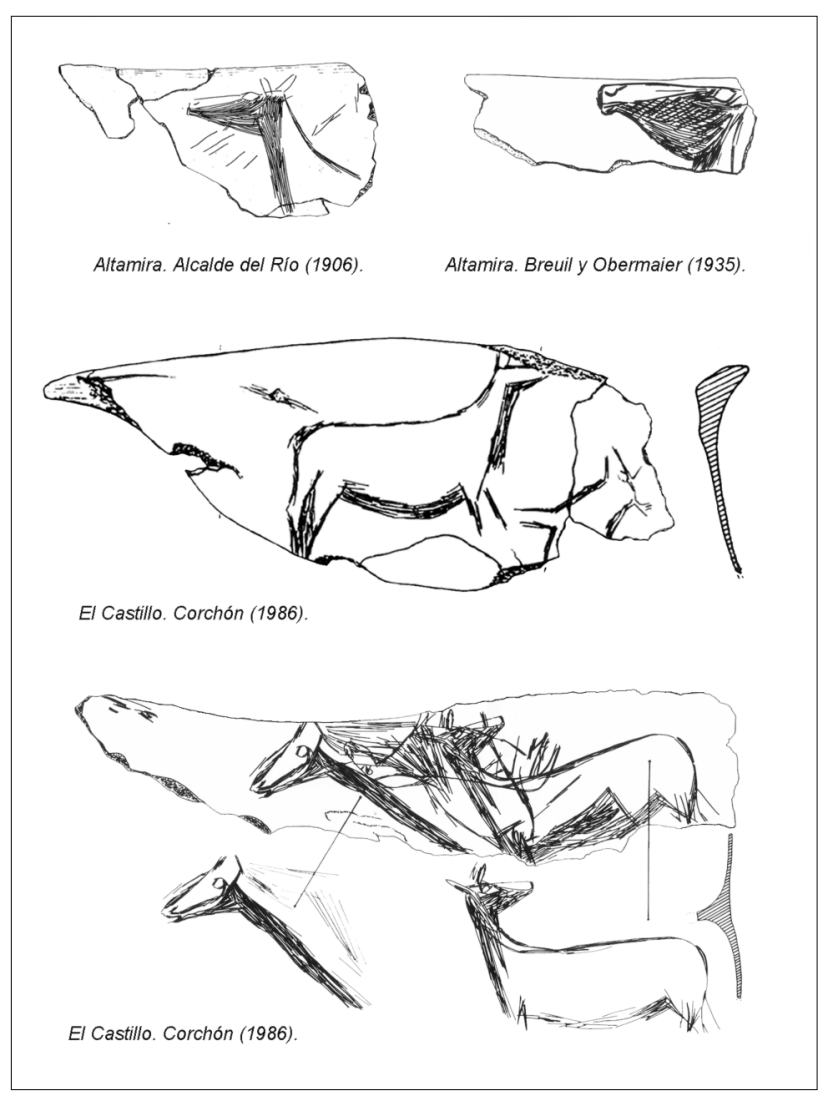

A Figura 2. Figuras de ciervas del Estilo IV antiguo. Iconografía del modelado en el arte mobiliar de los omóplatos de tipo Altamira y El Castillo. coincidiría grosso modo con la mejoría de las condiciones ambientales que registra el Tardiglaciar y con un paisaje de mayor cobertura vegetal que en momentos anteriores, que a buen seguro facilitó la mejoría de las posibilidades alimenticias del ciervo y aumentar la base anterior de ramoneo con el consumo de hierbas, flores, hojas, e incluso frutos.

La imagen más contundente de las cacerías sistemáticas y recurrentes de ciervo en los tiempos magdaleniense la tenemos reproducida en La Riera. La acumulación masiva de los restos de ciervos en los niveles datados en el 17.000 BP. responde en nuestra opinión a un tipo de asentamiento logístico muy concreto: un cazadero especializado. Eran esos lugares ocupados brevemente por partidas de cazadores para preparar y planificar las capturas de ciervos por las proximidades. De hecho, ciertos niveles magdalenienses de este yacimiento presentan con claridad los rasgos de los cazaderos típicos de la Facies Juyo (Utrilla, 1994). Pero la cueva no debió ser solo un lugar de habitación: a todas luces sirvió para tareas posteriores a la caza, para llevar a cabo las labores de descuartizamiento de los cadáveres de los ciervos y así procesar la carne para el traslado de las partes más rentables hacia un campamento residencial. La acumulación de piezas esqueléticas del ciervo procedentes de las partes más alimenticias (como costillas, vértebras, fémures...) revela hasta qué punto la cueva se convirtió en el basurero de desperdi-

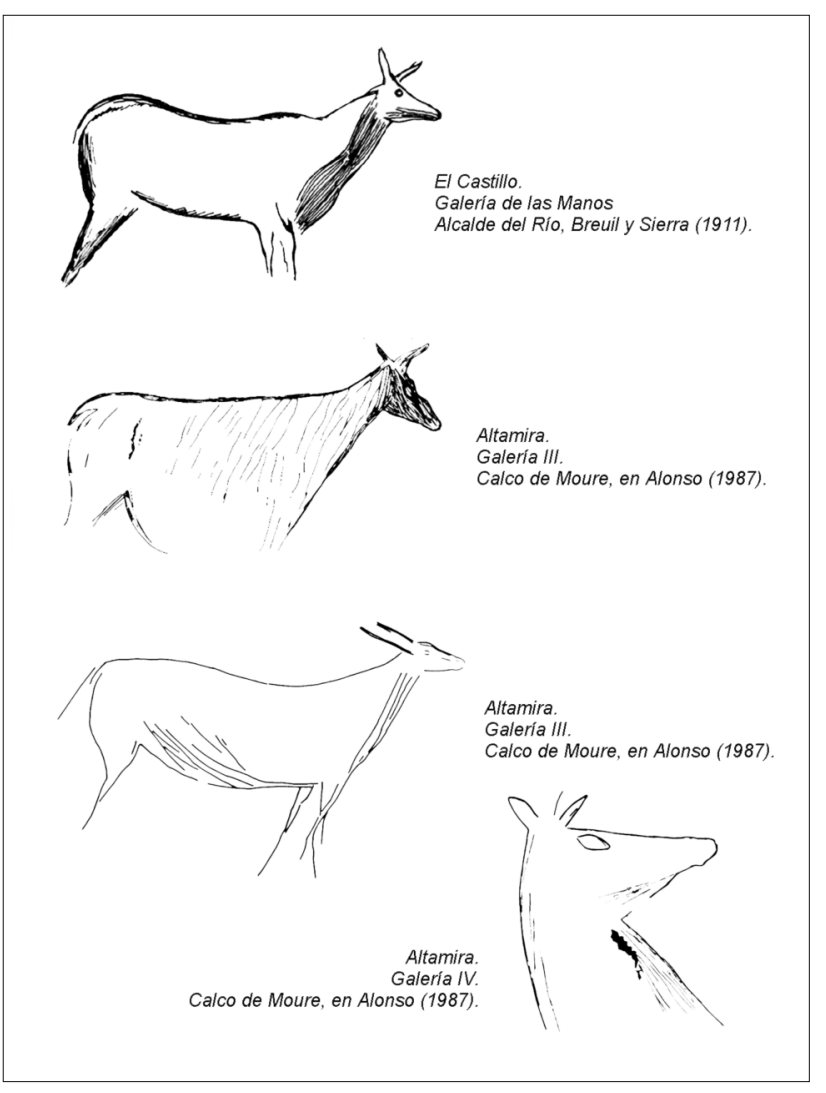

A Figura 3. Figuras de ciervas del Estilo IV antiguo. Modelados en trazos estriados en el arte rupestre de Altamira y El Castillo. 


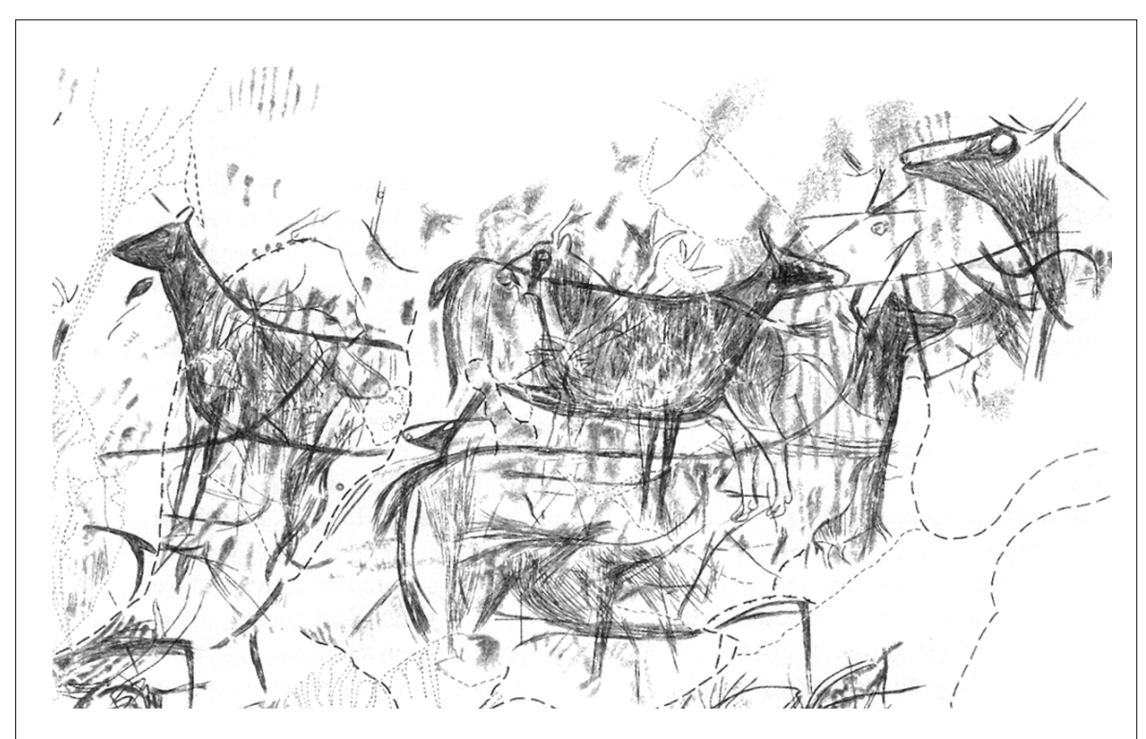

Llonín. Detalle del Panel Principal. Fortea, De la Rasilla y Rodríguez Otero (2004).
- Figura 4. Panel con representaciones de cérvidos del Estilo IV antiguo, correspondiente al

Magdaleniense inicial (16.000 BP. a 14.000/14.500 BP.). Modelo de composición y de iconografía en el arte rupestre en Llonín (Fase III). cios de un matadero donde se desarticulaba el animal y se descarnaban sus huesos. Este tipo de mataderos recuerdan las áreas de descuartizamiento de caribúes que habilitaban los nuniamut del norte de Alaska durante las matanzas de las manadas (Binford, 1983).

La constatación de matanzas masivas e indiscriminadas de ciervos merced al acecho de la manada resulta más creíble en estos momentos magdalenienses. El yacimiento de El Juyo ha dado muestras convincentes de perfiles catastróficos de mortandad en alguno de sus niveles de ocupación caracterizados como cazaderos que, con las oportunas precauciones, podrian interpretarse como resultado de matanzas colectivas, masivas y más o menos indiscriminadas sobre los distintos miembros que componian las manadas (Klein et al., 1981). No obstante, para obtener resultados decisivos habría que correlacionar los perfiles de mortandad obtenidos en los yacimientos con los modelos de comportamiento de los ciervos, pues ya hemos descrito que la composición de la manada difiere en función del sexo. Lamentablemente los datos arqueológicos sobre la relación sexual son precarios y los que existen apuntan hacia una realidad muy compleja. Basándose en la proporción de restos de cuernas y en el tamaño de los astrágalos J. Altuna ha supuesto que, mientras los cazadores de Tito Bustillo preferían los rebaños de ciervas con sus crías, los cazadores de Urtiaga se decidieron sobre todo por los machos (Altuna, 1976).

Este tipo de prácticas masivas de caza tienen un bien paralelo etnográfico en los modos de caza de ciervo que practicaban los extintos pobladores de las costas norteamericanas. Los relatos de los exploradores europeos testimonian las habilidades de caza de estos pueblos amerindios, que requerian numerosas tareas y reclutaban a multitud de personas del grupo. Las mujeres, niños e incluso ancianos ayu- daban en la tareas iniciales de acorralamiento de los ciervos, portando teas y golpeando toda clase de instrumentos sonoros para asustar a los animales, que en carrera desenfrenada eran encauzados intencionadamente por pasos naturales angostos, aprovechando accidentes topográficos del terreno y, si fuera necesario, colocando vallas o redes en el terreno. Los animales se internaban así en recintos naturales o cercados artificiales, detrás de los que se apostaban los cazadores en posición de disparo. Tácticas similares de acorralamiento eran usadas hasta no hace mucho por otros pueblos como los nuniamut, que construian rutas preparadas con barreras naturales (por ejemplo hileras paralelas de lomas glaciares) y relieves artificiales hechos de manera intencionada a modo de montículos de piedras (Binford, 1978).

De manera similar, los cazadores magdalenienses cantábricos habrian podido recurrir a las emboscadas de manadas de ciervos en los pasos angostos creados por los desfiladeros y los vados comprometidos de los ríos, particularmente durante las migraciones estacionales que recorrian los animales desde los pastos bajos de la costa hasta los pastos altos de las montañas (Straus, 1983). La predicción precisa de los movimientos migratorios del ciervo, que se traslada en marzo/abril a las tierras altas y regresa a las tierras costeras en octubre/noviembre, pudo permitir un acceso más cómodo a las capturas, una relativa seguridad en la planificación de los recursos y una optimización del trabajo. Esta posibilidad no deja de ser una hipótesis ya que es necesario desentrañar si la caza magdaleniense del ciervo se ajustaba a los ritmos estacionales de la especie. Los datos que tenemos acerca de la estacionalidad de las cacerías de ciervo para este período son todavía muy limitados. Las tablas que tenemos en La Riera, Ekain o Urtiaga sugieren una relativa concentración de ciervos juveniles en torno a finales de 
primavera o comienzos de verano, justamente en la época crítica post parto de las ciervas. Este período resulta en principio poco interesante para cazar hembras porque disponen de muy poca grasa corporal tras los gastos calóricos provocados por la gestación y la lactancia, pero resulta por el contrario muy aconsejable para la caza de machos adultos pues coincide con el momento álgido de su ciclo biológico (Mateos, 1999).

Hay otro hecho no menos significativo de las prácticas de caza que conocemos desde los primeros tiempos magdalenienses: la intensificación de la caza de los pequeños cervatillos recién nacidos (Quesada, 1998). Los numerosos dientes de leche recuperados en niveles magdalenienses muy antiguos de La Riera, Ekain o Urtiaga, prueban que la caza de cervatos de unos pocos días de vida se convirtió en una costumbre habitual y permitió contar con un suplemento de recursos de calidad. No podemos discernir aún si la elección de estos animales respondió al interés alimenticio por lo tierno de su carne o por la delicadeza de sus suaves pieles. En realidad la caza de cervatillos era conocida por los cazadores solutrenses de El Buxu en lo que parece un momento ya avanzado. La caza de estos pequeños animales resultaría una opción muy sencilla pues ya hemos descrito de qué manera permanece desvalida la cría en la paridera a merced de los predadores. Bastaría con acechar el lugar y aprovechar justo un momento de descuido de la madre para capturar al cervato en lo que parece ser más una práctica de recogida o recolección que de auténtica caza.

\section{EL CIERVO EN EL UNIVERSO ARTÍSTICO: ESTILOS E ICONOGRAFÍA DEL ARTE RUPESTRE Y MOBILIAR}

El ciervo, en cuanto especie, forma parte importante del bestiario representado en el arte paleolítico, como es bien sabido. Sin embargo, presenta notables diferencias diacrónicas según áreas y según se trate de machos o hembras. En este último sentido, el marcado dimorfismo sexual, llega a configurar como grupos independientes a machos y hembras de la misma especie, contrariamente a lo que ocurre con los restantes animales más frecuentemente representados en el imaginario paleolítico. Igualmente, las numerosas y rígidas convenciones en la representación de estos animales se ven afectadas por esta dualidad que no llega, en ningún caso, a ser absoluta. Es decir, todas las formas, técnicas y estilos de representación, así como las elecciones de emplazamiento y soporte, afectan a machos y a hembras; sin embargo, la cuantificación estadística sugiere diferencias que parecen sustanciales. Aunque sea de forma muy general, analizaremos alguno de estos casos, por lo demás recurrentes en la bibliografía.

En la primera sistematización del emplazamiento de los animales en la cueva, realizada por Leroi-Gourhan (1958) para su teoría interpretativa global del arte rupestre paleolítico, los ciervos son considerados como "animales laterales", situándose mayoritariamente en la entrada y menos frecuentemente al fondo de la cueva. Por el contrario, las ciervas se incluyen en el grupo de los "animales variables", junto con los renos, si bien su emplazamiento más frecuente está en el panel central o en su entorno. Los datos estadísticos manejados por Leroi-Gourhan muestran que la elección del emplazamiento según qué tema no es casual, sino intencionada. Ello a pesar de los problemas de orden cronológico que plantea una visión sincrónica del reparto y aquellos otros de tipo geológico, habida cuenta de la variabilidad e inestabilidad de los sistemas kársticos (González Sainz, 2005). Pero lo que aquí nos interesa destacar, al margen de la teoría global, es el tratamiento de machos y hembras de la misma especie como realidades diferentes.

El recuento general de especies representadas en el arte rupestre cantábrico más reciente que conocemos es el utilizado por C. González Sainz (2005) según los datos inéditos de R. Cacho (1999). Este trabajo, realizado sobre 65 cuevas que incluyen los últimos descubrimientos, no altera sustancialmente los porcentajes ya conocidos y que sirvieron de base para los trabajos clásicos de la segunda mitad del siglo pasado. Así observamos que la representación de ciervas es el capítulo más numeroso con 335 ejemplares, lo que supone el $23.28 \%$ del total. Esta proporción es similar a la registrada para los caballos, que cuentan con 319 representaciones y por tanto un $22.16 \%$. Los ciervos suponen el $10.42 \%$ del total con 150 ejemplares. Es decir, analizados los datos globalmente podemos decir que el animal más representado en el arte rupestre cantábrico es la cierva, seguida muy de cerca por el caballo.

En el arte mueble aparecen unos datos similares. En el último inventario general para el Cantábrico elaborado por Ma. S. Corchón (1986) se observan los altos porcentajes de ciervas, mayoritariamente concentradas en el Magdaleniense inferior, y de caballos en el Magdaleniense con arpones. No entramos en cifras concretas pues estos datos han sido desbordados por la avalancha de hallazgos mobiliares de las dos últimas décadas. Por cierto que estos hallazgos incorporan numerosas ciervas al capítulo Solutrense superior y Magdaleniense inferior (El Buxu, La Güelga, El Mirón, El Juyo, etc.)

En tiempos gravetienses y primeros momentos solutrenses las representaciones rupestres ya revelan un modelo iconográfico muy característico para el ciervo (particularmente para las hembras). En verdad no se trata de un modelo exclusivo de esta especie porque toma forma en otros animales como las cabras y con adaptaciones propias en caballos, uros... Pero las convenciones del Estilo III presentan al ciervo como un protagonista singular y parece probar el interés particular por una especie que todavía por entonces no trascendía en los modos de caza respecto de otos animales.

La iconografía del ciervo presenta una impronta peculiar muy particular desde las primeras imágenes artísticas naturalistas del Estilo III (fig.1). Esta circunstancia adquiere más notoriedad al comprobar que la cierva es el animal más representado en los santuarios exteriores de cronología graveto-solutrense como La Lluera, Godulfo, Santo Adriano, Los 
Torneiros, Chufín, etc. En una de las mejores representaciones de este modelo, la Gran Hornacina de La Lluera, la cierva domina numéricamente el panel al presentar una docena de figuras, si bien es cierto que la imagen de la media docena de grandes uros domina expresivamente la composición por los grandes volúmenes, su posición central y su dinámica. Las ciervas muestran un modelo muy estereotipado y alejado de la forma real, pero que resume con el diseño trilineal de forma simple y bella lo que parece una percepción intelectual (Fortea, 2005/06). La recreación artística de las ciervas se resuelve de manera contundente con tres trazos principales, que esboza sin solución de continuidad la silueta del animal. Es una convención sencilla pero expresiva porque proporciona a la figura una impronta dinámica, donde el alargamiento de la cabeza y el cuello hacia arriba recuerdan una actitud muy propia del estado de alerta de las manadas.

La trascendencia que adquiere el ciervo en las prácticas de caza de ciertos yacimientos de la última época solutrense tiene también su paralelo artístico en la presencia de santuarios monotemáticos protagonizados por la especie. En los momentos solutrenses del estilo III la presencia ubicua del ciervo constituye un rasgo principal del santuario más representativo de la Escuela de Ramales: Covalanas. El recuento de animales de la cueva no deja lugar a dudas sobre la hegemonía de la cierva: un animal representado 18 veces,

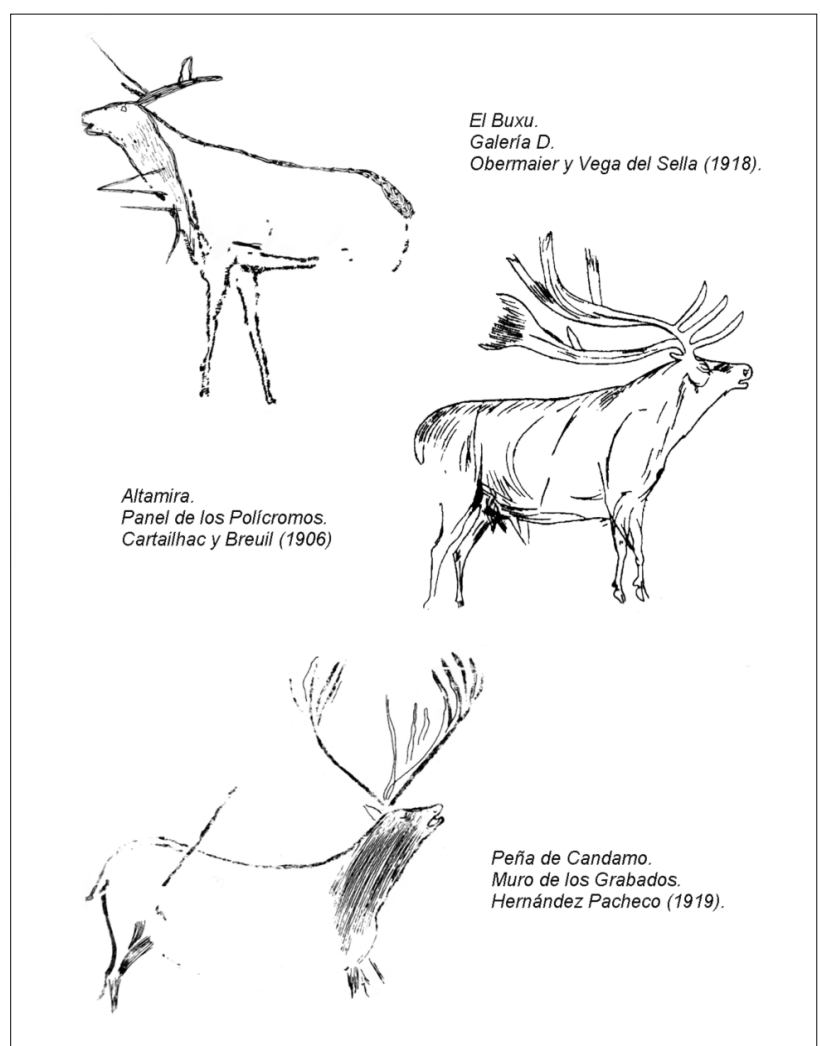

- Figura 5. Modelos iconográficos de representación del ciervo macho en el Estilo IV antiguo. El ciervo herido (El Buxu, Peña de Candamo) y el ciervo bramando (Altamira). por tan solo un caballo, un posible reno y un dudoso bóvido. Las similitudes técnicas y formales componen un modelo iconográfico peculiar para estos ciervos: pintura roja (ya tinta plana, ya trazo tamponado continuo o discontinuo), diseño triangular de la cabeza, representación de las dos orejas abiertas en $\mathrm{V}$, representación de despiece para la cruz y cueIlo... La datación de estos conjuntos en tiempos solutrenses del Inter Laugerie-Lascaux (debido a la presencia de renos, por Moure, González Sainz y González Morales, 1991) podría coincidir con un momento inmediatamente previo a los primeros intentos de la caza especializada de ciervo en ciertos lugares como La Riera... Resulta aún prematuro establecer correlaciones, pero parece sugerente pensar en la hegemonía del ciervo en la Escuela de Ramales no tan solo como una mera referencia conceptual: es la expresión de unos expertos conocedores del comportamiento de las manadas. El sentido narrativo de una composición tan emblemática como el conjunto principal de ciervas de Covalanas (Moure, González Sainz y González Morales, 1991) es una buena muestra de la capacidad de los artistas para reflejar un comportamiento de alerta de las manadas de ciervas que sin duda conocian en detalle los cazadores.

El siguiente testigo cronológico, las ciervas grabadas de trazo estriado del Magdaleniense inferior, nuevamente incorporan un modelo muy estereotipado y exclusivo del área cen-

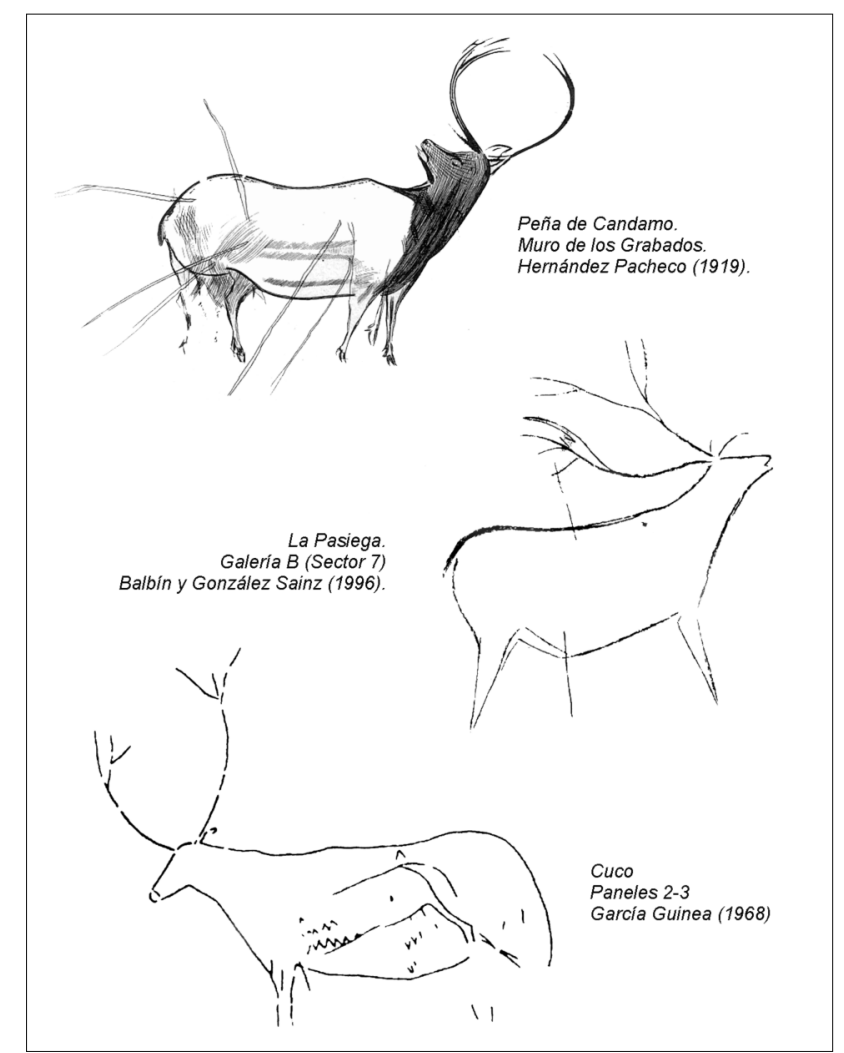

A Figura 6. Modelos iconográficos del ciervo del Estilo IV. 
tral de la Cornisa cantábrica (tanto en el arte mueble como rupestre) relacionado con el ciervo. De hecho la producción de grabados de trazo estriado tiene una relación intrínseca con las representaciones de ciervas. Las similitudes técnicas y formales en las muestras mobiliares presentan una iconografía común en El Cierro, El Juyo, El Mirón, Altamira y El Castillo (fig.2): trazo múltiple para contornear el animal, y haces de estriados para marcar despieces y sombreados en el interior de la cabeza y cuello (no obstante hay grandes diferencias entre los calcos de Almagro, 1976; Corchón, 1986; y Fernández Lombera, 2003). Las muestras mobiliares recuperadas en El Mirón sugieren la horquilla 16.000-15.000 BP. y las de Altamira 15.000-14.000 BP., lo que coincide con el momento de caza intensiva del ciervo en un marco probable de capturas masivas o indiscriminadas a modo de matanzas catastróficas en un lugar como El Juyo. Recordemos que este modelo iconográfico del ciervo/a presenta también una expresión parietal en ciertos santuarios (fig. 3). Hay representaciones más o menos similares en Tito Bustillo, Les Pedroses, La Garma, Altamira, El Castillo, Emboscados y Cobrantes. La manifestación más espléndida no solo por la cantidad de representaciones sino también por la belleza se halla en la fase III de Llonín (Fortea, De la Rasilla y Rodríguez, 2004; fig. 4), si bien en la cueva asturiana no se han hallado los correlatos mobiliares.

Este tipo de convenciones ejemplifican magníficamente la importancia de estos animales en la vida de los cazadores paleolíticos cantábricos y muestran a la par el conocimiento profundo del comportamiento animal. En este panorama podemos comprender mejor otras convenciones iconográficas del ciervo plasmadas de manera reiterada por los artistas. Ese es el caso de la figura del animal que vuelve la cabeza, asociada a la técnica del grabado estriado o sombreado característica del Magdaleniense inferior. Igualmente, asociando el grabado estriado y la figura retrospiciente hallamos el tema del ciervo herido bramando. La figura emblemática de este conjunto de convenciones es el majestuoso ciervo herido por venablos que aparece en el Muro de los grabados de la Peña de Candamo, tan bellamente reproducido por J. Cabré. En realidad hay representaciones similares entre las estilizadas ciervas tamponadas en rojo de estilo Ramales, que con la vuelta de la cabeza anuncian una convención que cristalizará durante el Magdaleniense inferior.

Pero la mejor prueba de la relación entre la caza y el arte la hallamos en el conocido tema del ciervo herido (figs. 5 y 6). Los animales lacerados por venablos muestran un estereotipo marcado por los siguientes rasgos: trazos a modo de lanzas clavadas en el tronco y cuello, postura retrospiciente, actitud de bramar (González Sainz, 2007/08) y tipificación como ciervo macho (Utrilla y Martínez-Brea, 2005/06) con representación de magníficas cornamentas que prueba la trascendencia de este rasgo tan peculiar. Ciertamente así se constata en la mayoría de los casos. Pero una vez más encontramos algunas excepciones que no permiten categorizar las afirmaciones. No todos los ciervos heridos vuelven la cabeza, como es evidente en las representaciones trilineales graveto-solutrenses así como en numerosos ejemplos rupestres posteriores (La Pasiega, El Buxu, Peña de Candamo...). Tampoco todos ellos son machos, como muestra el excelente grabado de una cierva herida en una plaqueta del nivel 2, Solutrense superior, de la cueva de El Buxu (Menéndez, 2003). Finalmente, conocemos algunas hermosas ciervas retrospicientes, como las grabadas en los omóplatos del Castillo, que no muestran heridas o actitud de dolor.

Esta dificultad de encasillar cronológicamente algunas de las convenciones asignadas a la representación de ciervos/as se ejemplifica magníficamente, a nuestro juicio, en la tibia grabada con tres cabezas de cierva de la Cueva de La Güelga (Menéndez y Martínez, 1991/92). En esta pieza, de cronología Magdaleniense inferior (fig. 7), aparecen asociadas figuras típicas de ese momento, similares en diseño a las grabadas sobre omóplatos en Altamira, El Castillo y ahora también en El Mirón, con otras cabezas de cierva de dibujo menos rígido y con convenciones en la representación de diferentes partes anatómicas y sentido volumétrico tradicionalmente asignadas al Magdaleniense con arpones, cuya pieza emblemática sería el bastón de El Pendo. Además de conocer, en este caso, el contexto exacto del hallazgo y su cronología, te-

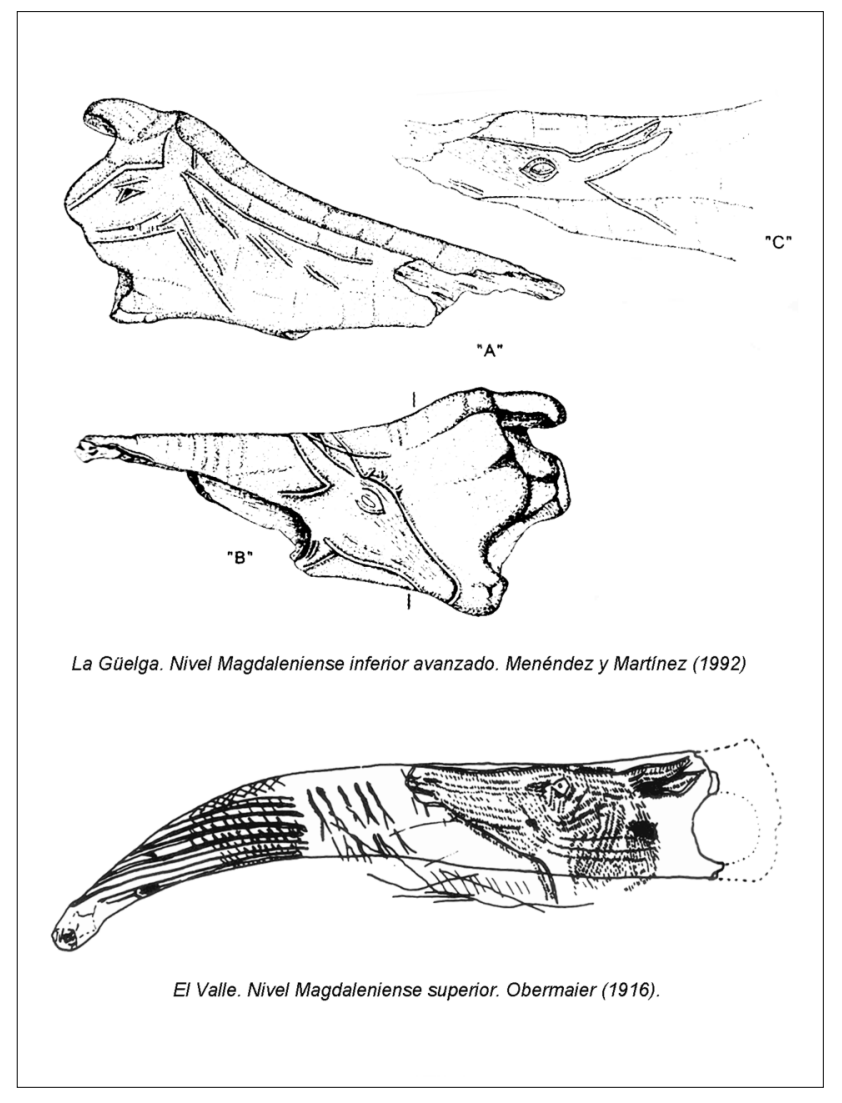

A Figura 7. La iconografía de la cierva en el arte mobiliar en el Tardiglaciar avanzado. La evolución desde la tibia de La Güelga (14.000 BP.) hasta el bastón de El Valle (circa 13.000-12.000 BP.) 


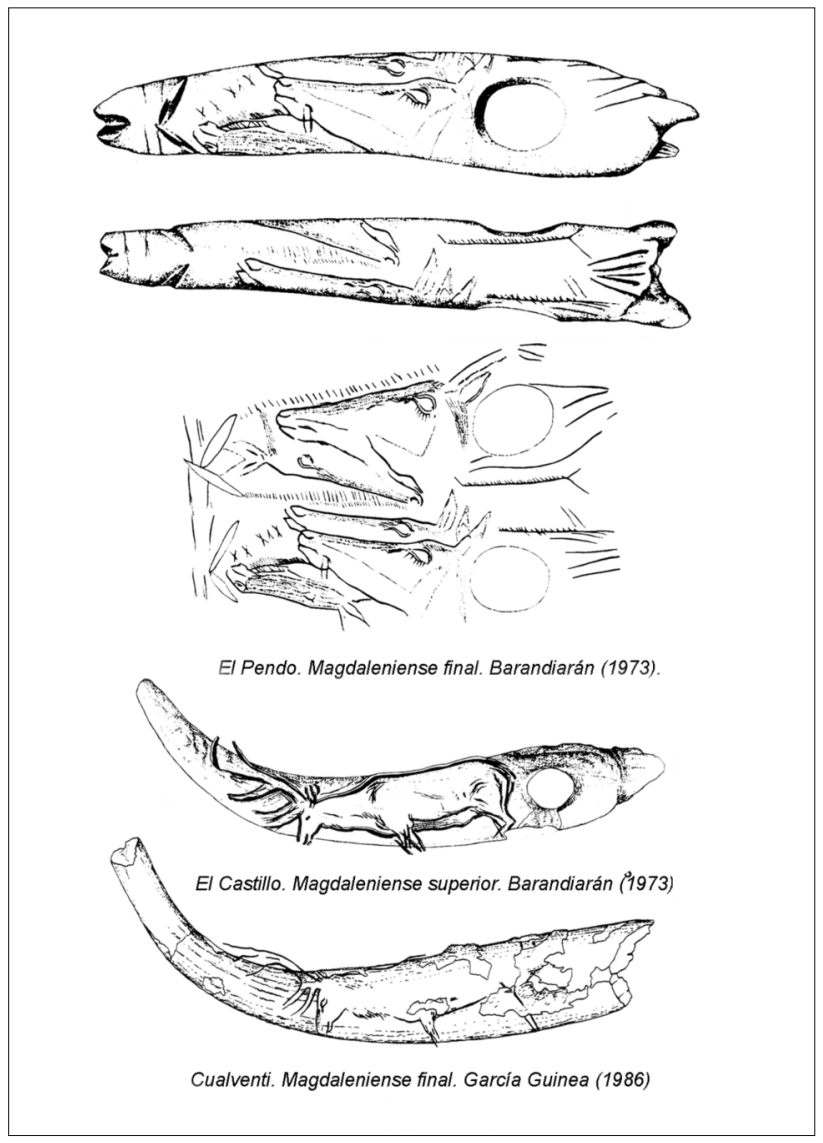

A Figura 8. La representación del ciervo en los bastones de mando del Magdaleniense superior y final. El apogeo del naturalismo del ciervo en el arte mobiliar. nemos la evidencia de que unas y otras se realizaron contemporáneamente en estilos diferentes. Esto no es un caso único, pero ilustra la rigidez que la visión historicista manejó tradicionalmente en el estudio del arte paleolítico.

La breve exposición anterior muestra cómo el tema de la cierva en sus diferentes modelos de representación ocupa un lugar primordial durante gran parte del Paleolítico superior cantábrico, incluso en su emplazamiento en la cueva (UtriIla y Martínez-Bea, 2005/06). Sin embargo esta situación cambia de manera rotunda hacia $14.000 \mathrm{BP}$, con la aparición de lo que parece un nuevo modelo de ocupación del territorio que incluye la intensificación de las relaciones a larga distancia (Utrilla, 1994; Corchón, 2004). Desde ese momento y hasta finales del Paleolítico serán caballos y bisontes los que ocupen ese lugar primordial, ya sin los estereotipos formales típica y exclusivamente cantábricos, sino con un aire muy afín a modelos transpirenaicos (Fortea, 2007). No obstante, durante estos momentos todavía se puede reconocer una iconografía particular para los ciervos, que toma cuerpo en una de las expresiones mobiliares de apariencia más significativas: los bastones de mando. Los ejemplares de El Valle y El Pendo (figs. 7 y 8 ) constituyen probablemente las mejores expresiones de las composiciones naturalistas de la especie, a juzgar por la representación de detalles en los hocicos, lacrimales, orejas, pelaje, fauces... Toda una revelación de la capacidad de los últimos artistas magdalenienses para recrear la Naturaleza a través de una especie que, a la postre, permitía su subsistencia.

\section{BIBLIOGRAFÍA}

AlCALde del Rio, E. (1906): Las pinturas y grabados de las cavernas prehistóricas de la provincia de Santander: Altamira, Covalanas, Hornos de la Peña, Castillo. Imprenta Blanchard y Arce. Santander.

AlCALde del Rio, E., BREUIL, H y SieRRA, L. (1911): Les cavernes de la région cantabrique (Espagne). Vve. A. Chéne. Mónaco.

Almagro, M. (1973): "Las pinturas y grabados de la cueva de Chufín. Riclones. Santandern. Trabajos de Prehistoria, 30: 9-67.

Almagro, M. (1976): Los omóplatos decorados de la cueva de "El CastiIlo." Puente Viesgo (Santander). Museo Arqueológico Nacional. Madrid.

ALONSO. R. (1987): "El modelado interior de los grabados rupestre paleolíticos del norte de la Penínsulan. En W.AA.: Estudios de Arte Paleolítico. Centro de Investigación y Museo de Altamira, monografía 15. Ministerio de Cultura. Madrid: 133-214

AltunA, J. (1976): "Los Mamíferos del yacimiento prehistórico de Tito Bustillo (Asturias)». En Moure, J. A. y Cano, M.: Excavaciones en la cueva de Tito Bustillo (Asturias). Boletín del Instituto de Estudios Asturianos, Oviedo: 149-194.

ALTUNA, J. (1994): "La relación fauna consumida-fauna representada en el Paleolítico superior cantábricon. En Chapa, T. y Menéndez, M. (Eds.): Arte Paleolítico. Complutum, 5: 303-312. Madrid.

AltunA, J. (1995): "Faunas de mamiferos y cambios ambientales durante el Tardiglaciar cantábrico». En Moure, J. A. y González Sainz, C. (Eds.): El Final del Paleolítico Cantábrico. Transformaciones ambientales y culturales durante el Tardiglacial y comienzos del Holoceno en la Región Cantábrica. Universidad de Cantabria, Santander: 77-117.
Azorit, C. Analla, M., Carrasco, R. y Muñoz Cobo, J. (2002): "Astas. Esqueleto y edad del ciervo (Cervus elaphus hispanicus) de Sierra Morena oriental: Estudio de correlación». Anales de biología, 24: 195-200.

BALBín, R. DE y Gonź́LEZ SAINZ, C. (1996): "Las pinturas y grabados paleolíticos del corredor B./ de la cueva de La Pasiega (Cantabria)». En Moure, J. A. (Ed.): "El Hombre Fosil" 80 años después. Universidad de Cantabria, Santander: 271-294.

Barandiarán, I. (1973): Arte mueble del Paleolítico cantábrico. Monografías Arqueológicas, 14. Zaragoza.

BINFORD, L.R. (1978): Nuniamut Ethnoarchaeology. New York.

BINFORD, L.R. (1983): In Pursuit of the Past. Decoding the Archaeological record. Thames and Hudson. Londres.

СACHO, R. (1999): Las representaciones animales en el arte rupestre paleolítico de la región cantábrica. Un acercamiento a su estructuración y variabilidad. Trabajo de investigación de III ciclo. Departamento de Ciencias Históricas. Universidad de Cantabria.

CartaIlHAC, E. y BreUIL, H. (1906): La Caverne d'Altamira à Santillana près Santander (Espagne). Imprimierie de Monaco. Monaco.

CORBET, G. (1966): The Terrestrial Mammals of Western Europe. London.

CORCHÓn, M. S. (1986): El Arte mueble paleolítico cantábrico: Contexto y análisis interno. Centro de Investigación y Museo de Altamira, monografía 16. Ministerio de Cultura. Madrid.

CORChón, M. S. (2004): «Europa 16500 - 14000 a. C.: un lenguaje común». En Arias, P. y Ontañón, R. (Eds.): La materia del lenguaje prehistórico. El arte mueble paleolítico en su contexto. Gobierno de Cantabria y Liébana 2006. Santander:105-126.

DARLING, F. (1963): A Herd of Red Deer. Londres. 
DEMARS, P. (2007): "La repartition des grands ongules en europe centrale et de l'ouest au paléolithique supérieurn. En Maillo, J. M. y Baquedano, E. (Eds.): Miscelánea en homenaje a Victoria Cabrera Zona Arqueológica, 7 (vol. I): 92-97. Alcalá de Henares.

FernándeZ-Lombera, J.A. (2003): Proporción y Autoría. Arte Mueble Paleolitico. Figuras de los Omóplatos de "El Castillo" (Puente Viesgo, Cantabria, España). Munibe (Antropología-Arkeologia), 55. San Sebastián.

FORTEA, J. (2005/06): «Los grabados exteriores de Santo Adriano. (Santo Adriano. Tuñón. Asturias)». Munibe, 57 (Homenaje a Jesús Altuna): 25-52.

FORTEA, J. (2007): "Apuntes sobre el arte paleolítico del oriente de Asturiası. En Ríos, S.; García de Castro, C.; De la Rasilla, M. y Fortea, J: Arte rupestre prehistórico del oriente de Asturias. Consorcio para el desarrollo rural del Oriente de Asturias y Nobel. Oviedo: 205-250.

FORTEA, J.: DE LA RASILLA, M. y RodrígUEZ, V. (2004): "Lárt parietal et la séce archéologique paléolithique de la Grotte de Llonín. (Peñamellera Alta. Asturies. Espagne)». Préhistoire, Arts et Societés, LIX: 7-29.

FreEMAN, L.G. (1971): "Significado ecológico de los restos de animales». En González Echegaray, J. y Freeman, L.G. (Coords.): Cueva Morín. Excavaciones 1966-1968, Patronato de las Cuevas Prehistóricas de la provincia de Santander. Santander: 417-437.

FREEMAN, L.G. (1973): "The significance of mammaliam faunas from Paleolithic occupations in Cantabrian Spain». American Antiquity, 38: 3-44.

García GuineA, M.A. (1968): Los grabados de la cueva de La Peña del Cuco en Castro-Urdiales y la cueva de Cobrantes (Valle de Aras). Patronato de las Cuevas Prehistóricas de la Provincia de Santander. Santander: 5-16.

GARCíA GUINEA, M.A. (1986): Los bastones magdalenienses en Cantabria. El hallazgo de Cualventi. UNED de Cantabria. Lección inaugural del curso 1986-87. Santander.

GonZÁlez SAINZ, C. (2005): «El punto de vista de los autores estructuralistas: a la búsqueda de un orden en las cuevas decoradas del Paleolítico Superiorn. En Lasheras, J. A. y González Echegaray, J. (Eds.): El significado del Arte paleolítico. Escuela de Cultura y Patrimonio "Marcelino San de Sautuola". Ministerio de Cultura: 181-209.

GonZÁLEZ SÁINZ, C. (2007/08): "El tema del "ciervo herido" en el arte parietal paleolítico de la región Cantábrica. Evaluación iconográfica». Veleia, 24-25. Homenaje a Ignacio Barandiarán: 305-327.

Hernández Pacheco, E. (1919): La caverna de La Peña de Candamo (Asturias). Comisión de Investigaciones Prehistóricas y Paleontológicas, memoria 24. Madrid.
Klein, R.G.; Wolf, C.; Freeman, L.G. y AlLwarden, K (1981): "The use of dental crown heights for constructing age profiles of red deer and similar species in archaeological samplesn. Journal of Archaeological Science, 8: 1-31.

LEROI-GouRHAN, A. (1958): "Repartition et groupement des animaux dans I'art parietal paléolitithique». Bulletin de la Societe Prehistorique Françoise, 55 (Fas. 9) : 515-528.

LUdT, B.C.; SChroeder,W.; RottMAnn,O. y Kuehn,R. (2004): "Mithocondrial DNA philogeography of red deer (Cervus elaphus)». Mol. Phylogenet.Evol., 3: 1.064-1.083.

Mateos, A. (1999): «El consumo de grasa en el Paleolítico superior. Implicaciones paleoeconómicas: nutrición y subsistencia». Espacio Tiempo y Forma. Serie I, Prehistoria y Arqueología, 12: 159-182.

MENÉNDEZ, M. (2003): «Arte prehistórico y territorialidad en la cuenca de río Sellan. El arte prehistórico de los comienzos del siglo XXI. Primer Symposium Internacional de Arte Prehistórico. Ribadesella: 185200.

MenÉndeZ, M. y MARTíneZ, A. (1991/92): «Una tibia con ciervas grabadas de la Cueva de La Güelga. Cangas de Onís. Asturiası. Zephyrus, 4445: 65-75.

Moure, J.A.; González Sainz, C. y González Morales, M.R. (1991): Las Cuevas de Ramales de la Victoria. Cantabria. Universidad de Cantabria. Santander.

Obermaier, H. y Vega del Sella, Conde de la (1919): La Cueva del Buxu. Comisión de Investigaciones Prehistóricas y Paleontológicas, memoria 20. Madrid.

QueSADA, J.M. (1995): :Las estrategias de caza durante el Paleolítico Superior Cantábrico. El caso del Oriente Asturiano», Complutum, 6 : 79-103.

QuesadA, J.M. (1998): La caza en la Prehistoria. Arco Libros (Colección Cuadernos de Historia, 56). Madrid.

StRAus, L.G. (1981): "On the habitat and diet of Cervus elaphus». Munibe, 3-4: 175-182.

StRAUS, L.G. (1983): El Solutrense vasco-cantábrico. Una nueva perspectiva. Centro de Investigación y Museo de Altamira, monografía 10. Ministerio de Cultura. Madrid.

UTRILLA, P. (1994): «Campamentos-base, cazaderos y santuarios. Algunos ejemplos del Paleolítico peninsularn. Homenaje a Joaquín González Echegaray. Museo y centro de Interpretación de Altamira, monografía 17. Ministerio de Cultura, Madrid: 97-113.

UtRILLA, P. y Martinez-BEA, M. (2005/2006): «La captura del ciervo vivo en el arte prehistórico». Munibe, 57 (Homenaje a Jesús Altuna, vol 3): 161-178. 